\title{
The Potential of Positive Obligations Against Romaphobic Attitudes and in the Development of 'Roma Pride'
}

\author{
Lilla Farkas \& Theodoros Alexandridis*
}

\begin{abstract}
The article analyses the jurisprudence of international tribunals on the education and housing of Roma and Travellers to understand whether positive obligations can change the hearts and minds of the majority and promote minority identities. Case law on education deals with integration rather than cultural specificities, while in the context of housing it accommodates minority needs. Positive obligations have achieved a higher level of compliance in the latter context by requiring majorities to tolerate the minority way of life in overwhelmingly segregated settings. Conversely, little seems to have changed in education, where legal and institutional reform, as well as a shift in both majority and minority attitudes, would be necessary to dismantle social distance and generate mutual trust. The interlocking factors of accessibility, judicial activism, European politics, expectations of political allegiance and community resources explain jurisprudential developments. The weak justiciability of minority rights, the lack of resources internal to the community and dual identities among the Eastern Roma impede legal claims for culture-specific accommodation in education. Conversely, the protection of minority identity and community ties is of paramount importance in the housing context, subsumed under the right to private and family life.
\end{abstract}

Keywords: Roma, Travellers, positive obligations, segregation, culturally adequate accommodation

\section{Introduction}

'A Persisting Concern: Anti-Gypsyism as a Barrier to Roma Inclusion' reads the title of the recent study by the Fundamental Rights Agency (FRA) on societal attitudes towards Europe's most despised minority group. ${ }^{1}$ In 2016, one out of three Roma experienced some form of harassment and 4\% reported racially motivated violence to researchers, but not necessarily to the authori-

* Lilla Farkas is a practising lawyer in Hungary and recently earned a PhD from the European University Institute entitled 'Mobilising for racial equality in Europe: Roma rights and transnational justice'. She is the race ground coordinator of the European Union's Network of Legal Experts in Gender Equality and Non-discrimination. Theodoros Alexandridis is a practicing lawyer in Greece.

1. European Union Agency for Fundamental Rights, A Persisting Concern: Anti-Gypsyism as a Barrier to Roma Inclusion (2018). ties. ${ }^{2}$ An ethnic minority with a distinct language, culture and traditions, the Roma regularly experience racial discrimination based on assumptions and prejudice.

Social deprivation within the group does not only mean that the priority needs of the Roma are fundamentally socio-economic, but that they lack strong middle classes that could maintain minority institutions and lead the (legal) struggle for Roma rights. The lack of standardised Roma language and the scarcity of teachers of Roma origin hamper claims for minority schools or language education. Structural changes within the Roma and Traveller communities require wide-ranging social intervention rather than simple restraint from states and majority populations.

Can positive obligations achieve attitudinal change by countering prejudice, and similarly, can they lead to structural changes in the education and housing of the Roma? Do positive obligations require restraint and/or adaptation from majority societies only, or do they also govern the choices of minorities? In order to answer these questions, the article focuses on the evolution of the positive obligations doctrine in the field of Roma rights, discussing case law from several international tribunals.

The best-known Roma rights cases deal with segregated education (the so-called Roma education cases), forced evictions and Romaphobic violence (death, bodily injury and forced sterilisation). The article focuses on education and housing, because positive obligations (indirectly) address majority as well as the minority communities in these contexts, unlike case law on racially motivated violence, which is heavily tilted towards the reform of law enforcement.

The extent of case law and recommendations covered in the article leaves no room for analysing the oversight of implementation, such as the work of the Council of Europe's Committee of Ministers. Similarly, domestic litigation that yields international verdicts in the first place and/or seeks to enhance compliance afterwards is not analysed. It must be noted, however, that domestic litigation in both education and housing is extensive. Case law and the recommendations of monitoring bodies are studied in a chronological order to reflect the

2. FRA, Second European Union Minorities and Discrimination Survey (EU-MIDIS II): Roma - Selected findings (2016); and FRA, Roma survey - Data in focus: Discrimination against and living conditions of Roma women in 11 EU member states 2014. 
emergence of legal opportunity structures and the trajectory of litigation tapping into these opportunities. This approach reflects the bottom-up nature of litigation and planning legal strategies as legal opportunities become available. However, it also entails different orders in the description of education and housing jurisprudence as concerns the relevant legal regimes.

The approaches of the relevant legal regimes to compliance vary. The positive obligations doctrine is key to the Council of Europe treaties, being less dominant in the jurisprudence of UN treaty bodies and more so in their monitoring work. Compliance with the relevant EU acquis is facilitated by the principle of direct effect and the primacy of EU law. ${ }^{3}$ These factors explain the focus on Strasbourg jurisprudence and UN monitoring mechanisms.

Treaty bodies address social change at the structural level, which brings concluding observations under the remit of analysis. The article sketches trends emerging from these processes with an eye on systemic issues that cannot properly be captured in complaint procedures. Guidance on the actions of state administrations vis-àvis citizens is generally provided in concluding observations, but tribunals also increasingly address the need to adopt more general measures, which have in fact become a frequent element of Strasbourg jurisprudence.

The limitations of space do not allow comparisons with other racialised minorities, but it must be noted here that the jurisprudence of international tribunals diverges as concerns the different groups. Importantly, while in the Strasbourg Court the Roma serve as a benchmark for racial discrimination, Islamophobia as a form of racism features high on the agenda of UN mechanisms. ${ }^{4}$ In Europe, Romaphobia is understood as discrimination based on racial or ethnic origin, while Islamophobia is framed under religious freedom or treated as a matter of religious discrimination, which, to date, has enjoyed a low level of protection, particularly in the European Court. ${ }^{5}$ Simultaneously, cases filed by Kurds, who suffer the most violent forms of ethnic persecution, are not considered under the prohibition of racial or ethnic discrimination by the Court.

Compliance is understood here as a continuum of formal compliance (legal reform), substantive compliance (institutional reform) and full compliance (social change) ${ }^{6}$ Interestingly, while measuring the impact of legal and institutional reform seems rather complicated, attitudinal changes are canvassed regularly with the involvement of the general and minority public in the

3. B. de Witte, 'Direct Effect, Primacy and the Nature of the EU Legal Order', in P. Craig and G. de Búrca (eds.), The Evolution of EU Law (2011), 323.

4. The Strasbourg Court has delivered approximately 80 judgements so far, establishing discrimination in $15 \%$ of these.

5. R. McCrea, 'Singing from the Same Hymn Sheet? What the Differences between the Strasbourg and Luxembourg Courts Tell Us about Religious Freedom, Non-Discrimination, and the Secular State', 5 Oxford Journal of Law and Religion 18 (2016).

6. T. Carothers, 'The Rule of Law Revival', 2 Foreign Affairs 77, at 100 (1998)
FRA's Eurobarometer and EU Minorities and Discrimination Surveys.

When exploring social change in the sense of changing hearts and minds, we place specific emphasis on the depiction of the media, education, civil society and community approaches in the rulings and concluding observations of international tribunals and monitoring bodies. We do so by exploring a) the extent to which these bodies identify positive state obligations towards the effective protection of the Roma and vulnerable groups within the Roma community, such as women, and b) the way in which they set out to change 'hearts and minds' by tackling prejudices and stereotypes.

Both majority and minority communities are socially and politically diverse, and changes may more easily occur within the elites and those committed to internationalism. Moreover, the further one looks from the geographic centre, the less visible the change may appear. Still, the judicial recognition of wrongdoing and apologies by recalcitrant states are important precursors of social change, in which judicial dialogue across the various tribunals plays a significant part, not least because such recognition feeds Roma self-esteem and facilitates legal mobilisation.

Measuring social change solely from the perspective of legal tools can yield only partial answers of which we are keenly aware when offering conclusions here. ${ }^{7}$ Domestic legal as well as political mobilisations and counter-mobilisations are key to understanding reality, meriting research from the bottom-up, rather than the topdown. ${ }^{8}$ In respect of Roma rights, the law has been but one tool of social change, augmented by political campaigns, awareness raising, training, education, development projects and grassroots organising. ${ }^{9}$

Still, owing to the symbolic nature of judgements and their ability to recognise the harm done to the dignity of minority individuals and communities, but also because of the weight of certain tribunals and the shaming effect of their rulings, the law has perhaps received more attention than other social change tools. Moreover, law is the prime vehicle of European integration, making the sensitisation about Roma rights a necessity. In this respect, the media has played a rather controversial role by fostering Romaphobic prejudice and intolerance in the general population.

The article concludes that positive obligations have achieved a higher level of compliance in housing by requiring majorities simply to tolerate the minority way of life in overwhelmingly segregated settings. Conversely, little has changed in education, where legal and institutional reform, as well as a shift in the hearts and minds of both majority and minority groups, would be necessary to dismantle social distance and generate mutual trust. The interlocking factors of accessibility, judicial activism,

7. Open Society Justice Initiative, Strategic Litigation Impacts: Insights from Global Experience (2018).

8. S.L. Cummings, 'Rethinking the Foundational Critiques of Lawyers in Social Movements', 85 Fordham Law Review 1987 (2017).

9. J. Bhabha, A. Mirga \& M. Matache (eds.), Realizing Roma Rights (2017) 
European politics, expectations of political allegiance and community resources explain jurisprudential developments. The weak justiciability of minority rights, the lack of resources internal to the community and dual identities among the Eastern Roma impede legal claims for culture-specific accommodation in education. In contrast, the protection of minority identity and community ties is of paramount importance in the housing context, subsumed under the right to private and family life.

The text is divided into five sections. The Introduction is followed by a short summary about the Roma minority and Roma rights, particularly as seen through the concluding observations of monitoring bodies. Section 3 summarises international norms and case law on education. Section 4 provides an analysis along the same lines on housing, and Section 5 carries the conclusions.

\section{The Roma, 'Roma Pride' and Roma Rights}

An introduction to the minority group, its ethnic identity and relevant human rights issues surfacing in the monitoring processes of international bodies is necessary to ground our analysis. First and foremost, the limitations and constraints to the community's use of (international) human rights law need to be emphasised. Socio-economic conditions, weak internal resources, the lack of minority-specific religion and religious institutions, as well as a high level of political and ethnic assimilation, constitute structural impediments to legal claim making on the part of the Roma and the Travellers, augmented by the lack of minority institutions.

The Roma minority group numbers seven million within the EU, two-thirds of whom live in Bulgaria, Romania, Hungary, Slovakia and the Czech Republic, countries referred to as 'Roma-dense'. ${ }^{10}$ France's Traveller community, the gens du voyage is sizeable; so are the Roma communities in Spain and Greece. There are various subgroups according to language, descent and/or traditions. The Eastern Roma are overwhelmingly sedentary, but for the Western Travellers, the 'travelling way of life' is a central identity element. ${ }^{11}$ This distinction generally denotes minority attitudes vis-à-vis majority populations and states: the former seeks to blend in, while the latter to stand apart. ${ }^{12}$ Given that the Roma live in nation states, despite their transnational

10. The term was coined in G. Kertesi and G. Kézdi, A Cigány Népesség Magyarországon (1998).

11. See, the Council of Europe Descriptive Glossary of terms related to Roma issues, version dated 18 May 2012. For estimates, see, J.P. Liegeois, Roma, Gypsies, Travellers (1994), at 34

12. E. Marushiakova and V. Popov, 'The Roma - A Nation without a State? Historical Background and Contemporary Tendencies', in B. Streck (ed.), Segmentation und Komplementarität. Organisatorische, ökonomische und kulturelle Aspekte der Interaktion von Nomaden und Sesshaften (2004) 71 character, there is a strong tendency to identify as both a Roma and a citizen of a particular European state.

Roma denotes a collective label that more or less adequately reflects self-identification in the Roma-dense countries and for reasons of political exigence includes Western Travellers, a non-sedentary group. ${ }^{13}$ Roma rights is a widely used term, and we conceive of it as encompassing not only claims as a minority, but also as a racialised, poverty-stricken, excluded and subordinated 'pariah' group. ${ }^{14}$ Romaphobia is used to denote antiRoma, anti-Gypsy and anti-Traveller stereotypes. While being the most sizeable racialised minority in Central and Eastern Europe (CEE), the Roma are marginal in Western Europe, where European Muslims and Afro-Europeans occupy central place in policy processes. In the CEE, the Roma are not a politically dominant minority group, and the European 'silence on race' prevents them from becoming the 'archetypical' racial minority. ${ }^{15}$

Social deprivation and exclusion are reinforced by unemployment ranging between 50 and $70 \%$, which indicates the inability to break out of illegal or substandard labour conditions. ${ }^{16}$ Housing conditions are dire, particularly because the de facto toleration of Roma dwellings on state-owned land was not regulated after the political transition, which continues to undermine security of tenure for those living in segregated Roma districts. Access to schools is generally not a problem, unlike dropout and absenteeism. On paper, the Roma enjoy equal rights, but their residence status may be unresolved, impeding not only participation in public life, but also access to basic social services.

With notable exceptions, ${ }^{17}$ public administrations do not promote Roma rights, or worse, are part of the problem of non-implementation of both minority-focused and poverty-reduction policies. ${ }^{18}$ This leaves the representation of collective interests to progressive ethnopolitical formations that successfully resist the pressure of co-optation, friendly public institutions and the civil sector.

There is a strong expectation vis-à-vis the Roma to assimilate or suffer the consequences of social exclusion, but simultaneously, widespread Romaphobic attitudes diminish the chances of integration. These structural conditions undermine identity-based political organisation and diminish appetite for collective interest representation concerning minority identity. The preserva-

13. Gy. Csepeli and D. Simon, 'Construction of Roma Identity in Eastern and Central Europe: Perception and Self-Identification', 30 Journal of Ethnic and Migration Studies 129 (2004).

14. I. Pogány, 'Pariah Peoples: Roma and the Multiple Failures of Law in Central and Eastern Europe', 21(3) Social \& Legal Studies 375 (2012).

15. A. Lentin, 'Europe and the Silence about Race', 11 European Journal of Social theory 496 (2008).

16. D. Ringold, M.A. Orenstein \& E. Wilkens, Roma in an Expanding Europe: Breaking the Poverty Cycle (2004).

17. A. Krizsán, 'Ombudsmen and Similar Institutions for Protection Against Racial and Ethnic Discrimination', 4 European Yearbook Minority Issues 62 (2004).

18. Gy. Csepeli and A. Örkény, 'Az emancipáció kihívása a mai magyar társadalomban a romák és nem romák viszonyában', Szociológiai Szem/e 85 , at 90 (2015) 
tion and cultivation of 'Roma pride', that is, positive minority identity is thus left to the private sphere, despite recent political mobilisation. ${ }^{19}$

The Roma became visible in the mid-1990s through legal advocacy efforts in international organisations. Before international case law emerged from the early 2000s on, Roma rights advocacy had already generated important soft law measures. The Roma issue was taken up simultaneously by Council of Europe and UN monitoring bodies. Focusing on treaty mechanism, we begin with the Advisory Committee to the Council of Europe's Framework Convention for the Rights of National Minorities (FCNM), but due to the volume of output, focus more on UN monitoring mechanisms.

The Roma are recognised as a national/linguistic minority in the CEE. This is partly due to the minority conditionality set by the EU prior to accession, manifested in the requirement to sign and ratify the FCNM. ${ }^{20}$ It is important to note in the Western and Southern European context that regardless of political considerations, non-recognition or mis-recognition at the national level should not prevent the judicial protection of ethnic minority rights, including the use of language and other traditions. $^{21}$

The FCNM Advisory Committee has dealt with rights to/in education, particularly minority language education and multicultural education. It has observed that the equal access of Roma children to good quality education and their integration is a persistent problem across the Council of Europe, with school segregation representing the most extreme example. ${ }^{22}$ The bullying/harassment of Roma children, inappropriate and culturally biased tests, non-recognition of the Romani language and the lack of provision for socially disadvantaged Roma students constitute the key issues of concern. The Advisory Committee calls for the equal treatment of Roma girls, the offering of school meals, introduction of public transportation and training of Roma school assistants and teachers, stressing that teaching of and through the medium of the Romani language is a necessary element of ensuring access to education. ${ }^{23}$

The UN Committee on the Elimination of All Forms of Racial Discrimination (CERD) adopted a General Recommendation on Discrimination Against the Roma in $2000 .^{24}$ Its key recommendations address the need to 1 . enact or amend legislation prohibiting racial discrimination; 2. adopt and implement national strategies and programmes, and express political will and leadership; 3. recognise the Roma's minority or other status in con-

19. A. McGarry, Romaphobia: The Last Acceptable Form of Racism (2017).

20. P. Vermeersch, 'Minority Policy in Central Europe: Exploring the Impact of the EU's Enlargement Strategy', 3 The Global Review of Ethnopolitics 3 (2003).

21. UN Human Rights Committee, Bikramiit Singh v. France, Communication No. 1852/2008 (2012)

22. Advisory Committee on the Framework Convention for the Protection of National Minorities, Commentary on Education under the Framework Convention for the Protection of National Minorities, 21 (2006).

23. Ibid., at 25 .

24. CERD General Recommendation XXVII on Discrimination against Roma, A/55/18, annex V (2000) sultation with the minority; 4. mainstream policies on Roma women; 5. develop and encourage dialogue between Roma communities and central/local authorities, as well as between Roma and non-Roma communities, to promote tolerance and overcome prejudice and negative stereotypes on both sides.

When it comes to Roma-dense states, access to education as well as school segregation are treated as a priority issue, although access to housing, employment and healthcare also features high in the recommendations of UN treaty bodies. In relation to Western European countries with sizeable Roma and Traveller communities, the monitoring bodies seem more preoccupied with the need to resolve personal and group status, as well as access to culturally adequate housing. ${ }^{25}$ The need to properly regulate the status of Roma and Travellers in Western and Southern Europe is a recurring issue. ${ }^{26}$

Following the global crisis in 2008, with the rise of populist and racially intolerant voices, CERD and the Human Rights Committee raised the alarm about the sharply increasing level of hate speech and states' inability or unwillingness to investigate every incident and punish perpetrators, including politicians. ${ }^{27}$ The situation escalated to such a degree that the CERD appealed to the president of the European Commission in order to increase vigilance. ${ }^{28}$

The link between widespread prejudice and hate speech has been regularly made, ${ }^{29}$ along calls for unbiased and inclusive educational materials and methodologies of teaching to tackle stereotypes. The Committee on the Elimination of All Forms of Discrimination Against Women has emphasised the necessity of weeding out intersectional stereotypes that negatively affect Roma girls, whose school attendance is also hampered by traditions, such as early marriage. ${ }^{30}$

25. See, for instance, Concluding observations of the Committee on the Elimination of Racial Discrimination on France, 3 (2010).

26. See, for instance, Human Rights Committee, Concluding observations on the sixth periodic report of Italy, 3 (2017).

27. See, for instance, Committee on the Elimination of Racial Discrimination, Concluding observations on the combined nineteenth and twentieth periodic reports of Italy, 3 (2017). See, also, Human Rights Committee, Concluding observations on the fourth periodic report of Czechia, 4 (2019).

28. CERD letter to the president of the European Commission, 27 August 2010.

29. See, Committee on Economic, Social and Cultural Rights, Concluding observations on the combined third to fifth periodic reports of Romania, 4 (2014). See also, Committee on Economic, Social and Cultural Rights, Concluding observations on the second periodic report of the Czech Republic, 3 (2014).

30. See, for instance, Committee on the Elimination of Discrimination against Women, Concluding observations on the sixth periodic report of the Czech Republic, 7 (2016). See, also, Committee on the Elimination of Discrimination against Women, Concluding observations on the combined seventh and eighth periodic reports of Romania, 11 (2017). 


\section{Roma Rights in the Field of Education}

Roma-relevant legal provisions derive from multiple sources, including UN, Council of Europe and EU treaties and directives, as well as countless soft law measures adopted by international organisations. National legislation completes the normative basis, and inconsistencies among the distinct legal regimes surface in domestic litigation, which may or may not lead to international adjudication.

In general, international treaties protect the rights to education alone, as well as in conjunction with the prohibition of discrimination. UN treaties specifically address the treatment of minorities in relation to substantive human rights, while the European Court's interpretation of the principle of equal treatment can achieve the same result, albeit with a 'different speed'. ${ }^{31}$ Strasbourg jurisprudence reads the duty to accommodate cultural differences into substantive rights in relation to forced evictions, but it remains to be seen whether the Court would also follow this approach as concerns minority education.

\subsection{International Law Governing the Right to (Racially Equal) Education}

International standard setting on the right to education began after World War II. This section reviews relevant treaty provisions in a chronological order to ground the analysis in the following section.

\subsubsection{UN Standards and Supervisory Practice}

The Universal Declaration of Human Rights (1948) was the first instrument to assert the principle of non-discrimination and proclaim the right to education. The first education- and minority-specific treaty, the Convention Against Discrimination in Education (CADE), was adopted by the United Nations Educational, Scientific and Cultural Organisation (UNESCO) in 1960.

CADE prohibits discrimination and exclusion based on racial or ethnic origin. ${ }^{32}$ Exceptions to the prohibition of spatially separated educational institutions must be specifically permitted to be acceptable under CADE. The integrationist rationale behind the prohibition of segregation and the limitation of self-segregation in CADE and subsequent UN treaties - stems from the fear of secession in territories inhabited by minorities. ${ }^{33}$

CADE's approach to segregation can be characterised as a prohibition with exceptions, meaning that self-segregation is permitted subject to stringent conditions. ${ }^{34}$ Segregation for linguistic reasons is permissible but rarely used by the Roma themselves, because the structural conditions of minority language education are largely missing, and in practice, language does not seem to compel Roma communities to self-segregate. ${ }^{35}$ Strong allegiance with the majorities in the CEE may also strengthen this trend.

CADE envisages a system in which states bear a duty not to intervene in self-segregation promoting minority identity through the medium of language. It defines the content and manner in which parental choice can be made and professed. It also sets out the criteria under which the state must exercise control over parental choices in the best interest of the child - even though the term as such is not used in CADE.

The International Convention on the Elimination of All Forms of Racial Discrimination (ICERD) adopted in 1965 and in force since 1969 has been signed and ratified by all EU member states. It prohibits both direct and indirect racial discrimination ${ }^{36}$ and categorically prohibits segregation ${ }^{37}$ in the enjoyment of the right to education'. ${ }^{38}$ The CERD Committee has interpreted this provision as prohibiting spontaneous, unintended de facto - physical separation as well. ${ }^{39}$

Relatively few EU member states permit individual applications to CERD, which may explain the lack of petitions on Roma and education. CADE and ICERD prohibit segregation even if it is not intentional, coercive or absolute in terms of racial or ethnic proportions. Importantly, the European Court of Human Rights (ECtHR) seems not to accord a central place to these treaties in its jurisprudence, thus ICERD has served as a reference only as far as the definition of racial discrimination is concerned.

Article 24(1) of the International Covenant on Civil and Political Rights (ICCPR) provides every child protection by her family, society and the state without racial or ethnic discrimination. Article 27 of the Covenant confers a right on individuals belonging to ethnic, religious or linguistic minorities to

not be denied the right, in community with the other members of their group, to enjoy their own culture, to profess and practice their own religion, or to use their own language. ${ }^{40}$

Article 28 of the Convention on the Rights of the Child (CRC) guarantees the right to education, while Article 30 guarantees individual minority rights in a fashion identical to Article 27 ICCPR.

The International Covenant on Economic, Social and Cultural Rights (ICESCR) ensures the right to education (Art. 13) and prohibits discrimination on the basis

31. K. Henrard, 'The European Court of Human Rights, Ethnic and Religious Minorities and the Two Dimensions of the Right to Equal Treatment: A Jurisprudence at Different Speeds?', 34(03) Nordic Journal on Human Rights 157 (2016).

32. UNESCO Convention against Discrimination in Education (hereinafter: CADE), Art. 1(1).

33. P. Thornberry, The International Convention on the Elimination of All Forms of Racial Discrimination: A Commentary (2016).

34. CADE, Art. 5(1)(c).

35. CADE Art. 2(b)).

36. ICERD Art. 1(1).

37. ICERD Art. 3.

38. ICERD Art. 5(e)(v).

39. CERD, General recommendation, Racial segregation and apartheid (XIX), (1995).

40. CCPR General Comment No. 23: Art. 27 (Rights of Minorities) (1994). 
of racial or ethnic origin (Art. 2(2))..$^{41}$ An important consideration is that even though EU member states have signed and ratified the ICESCR, only a tiny minority permit individual complaints under the optional protocol. ${ }^{42}$ This may of course explain the lack of case law as concerns Roma and education.

In the Roma-specific General Recommendation, the CERD calls on states to support inclusion in the school system - in particular of Roma girls - to prevent and avoid segregation, 'while keeping open the possibility for bilingual or mother-tongue tuition', and to adopt measures in cooperation with Roma parents, in the field of education, to train Roma teachers and assistants; to improve dialogue and communication between the teaching personnel and Roma children, Roma communities and parents; to include in textbooks, chapters about the history and culture of Roma.

UN treaty bodies have used this General Recommendation as a benchmark, focusing more on special minority rights in the Western context and non-discrimination in the East, with tolerance building and the combatting of stereotypes as an overarching policy. In the East, the CERD Committee recommendations extend to increasing preschool attendance and decreasing dropout rates, ${ }^{43}$ to teachers and parents being familiarised with desegregation measures, ${ }^{44}$ to developing a desegregation plan including the redesign of compulsory school districts and sanctioning schools that refuse the admission of Roma children. ${ }^{45}$ In the Italian context, the Committee recommended to ensure that Roma, Sinti and Camminanti children are able to access quality education that is culturally and linguistically appropriate, at schools that are geographically accessible and where they suffer no negative treatment by staff or students. ${ }^{46}$

\subsubsection{Council of Europe}

Under Article 14 of the European Convention on Human Rights and Fundamental Freedoms, the enjoyment of the rights and freedoms set forth in the Convention must be secured without discrimination on the ground of racial or ethnic origin, and so on. Under Protocol I Article 2,

No person shall be denied the right to education. In the exercise of any functions which it assumes in relation to education and to teaching, the State shall respect the right of parents to ensure such education and teaching in conformity with their own religions and philosophical convictions.

Committee on Economic, Social and Cultural Rights, General Comment 11 (1999).

42. Only Belgium, Finland, France, Italy, Luxembourg, Portugal, Slovakia and Spain signed and ratified the optional protocol.

43. CERD, Concluding observations on the combined twentieth to twentysecond periodic reports of Bulgaria, 5 (2005).

44. CERD, Concluding observations of the Committee on Romania, 3 (2010).

45. CERD, Concluding observations on the combined twelfth and thirteenth periodic reports of Czechia (2019).

46. CERD, Concluding observations on the combined nineteenth and twentieth periodic reports of Italy, 6 (2017).
The Convention does not explicitly require states to accommodate ethnic minority children on a par with children belonging to a religious minority when it comes to education. Article 14 safeguards the principle of equal treatment, and the ECtHR applies the same test to both direct and indirect discrimination, meaning that it permits states parties to submit justification defences even in the case of direct racial discrimination and segregation. $^{47}$

Protocol 12 of the ECHR adopted in 2000 guarantees the right to equal treatment in all walks of life and explicitly covers direct and indirect discrimination. Neither the Convention nor Protocol 12 specifically prohibits harassment and segregation. It is important to note that while all EU member states are party to the Convention, Protocol 12 has been signed and ratified by only ten EU countries. ${ }^{48}$ This partly explains why the ECtHR has been seized upon to adjudicate racial discrimination in education with reference to the right to education and the principle of equal treatment, rather than the right to equal treatment in the field of education.

The level of ratification by EU member states of the European Social Charter (Revised) - which covers education - is low, and few permit NGOs to raise collective complaints against states before the European Committee of Social Rights (ECSR). ${ }^{49}$ The majority of collective complaints concerning the Roma pertain to housing. ${ }^{50}$

The FCNM guarantees the right to minority education. It was adopted in 1994 and entered into force four years later; however, it has a weak enforcement mechanism reporting by the Advisory Committee ${ }^{51}$ - so the right to minority education under it is not justiciable in court. The Council of Europe's Charter for Regional or Minority Languages safeguards minority language rights. ${ }^{52}$ While national minorities that have European kin states are relatively well catered for, Romanes is among the languages that receive a lower level of protection. Both aspects diminish the salience of this otherwise non-justiciable instrument when it comes to the Roma.

Establishing and maintaining ethnic minority schools is a collective right, as spelt out in Article 5(1) CADE and Article 13 of the Council of Europe's FCNM. The goal of minority education is the preservation of minority

47. L. Farkas, Segregation of Roma Children in Education: Addressing Structural Discrimination Through the Race Equality Directive (2007) and L. Farkas, Report on Discrimination of Roma Children in Education (2014).

48. Protocol 12 to the ECHR is ratified by the following EU member states: Croatia, Cyprus, Finland, Luxembourg, Malta, Netherlands, Portugal, Romania, Slovenia, Spain.

49. Additional Protocol to the European Social Charter Providing for a System of Collective Complaints is ratified by Belgium, Croatia, Cyprus, Czech Republic, Finland, France, Greece, Ireland, Italy, Netherlands, Portugal and Sweden.

50. O. de Schutter, The European Social Charter in the Context of Implementation of the EU Charter of Fundamental Rights (2016).

51. G. Gilbert, 'The Council of Europe and Minority Rights', 18 (1) Human Rights Quarterly 162 (1996)

52. F. De Varennes, 'Language Rights as an Integral Part of Human Rights', 3 (1) International Journal on Multicultural Societies 15 (2001). 
identity, in which instruction in the minority language plays an instrumental role. In its general recommendations on specific minority groups, the CERD Committee explicitly calls on states to ensure that mother tongue and bilingual education are guaranteed..$^{53}$ The FCNM Advisory Committee has developed its 'jurisprudence' along the same lines, mindful of the importance of interethnic relations even when minority education is self-segregated. As mentioned, the justiciability of these instruments is extremely limited, leading to a situation in which framing complaints in terms of equal treatment is easier than having recourse to special rights.

\subsubsection{The EU}

The 2000 EU Racial Equality Directive (RED) prohibits racial or ethnic discrimination in education without, however, explicitly prohibiting segregation. ${ }^{54}$ This makes adjudication in the EU amenable to qualification debates, that is, questions on whether segregation should be interpreted as direct or indirect discrimination, or indeed, whether EU anti-discrimination law can be read in a way that establishes this type of unequal treatment as a sui generis form of discrimination. ${ }^{55}$

It is important to note that the EU has manoeuvred itself into this situation by failing to act in time, due mainly to dissipating political support. A recommendation for the adoption of a Roma-specific directive explicitly prohibiting segregation and imposing a duty on member states to take positive action measures to remedy structural discrimination was made in 2004, to no avail. ${ }^{56}$ Since then, several policy measures, including the 2011 EU Framework for National Roma Integration Strategies, ${ }^{57}$ and desegregation guidance have been issued to spur compliance, with mixed results. ${ }^{58}$

The Court of Justice of the EU (CJEU) does not have power to impose positive obligations on member states in preliminary reference proceedings, whose aim is to assist and guide the national courts of member states in the interpretation of EU law. In proceedings initiated by the European Commission against member states for their failure to comply with EU law, the CJEU's powers are limited to establishing non-compliance and levying a fine. The European Commission has not launched judi-

53. K. Henrard, Equal Rights $v$ Special Rights: Minority Protection and the Prohibition of Discrimination (2007), at 49.

54. G. Cardinale, 'The Preparation of ECRI General Policy Recommendation No. 7 on National Legislation to Combat Racism and Racial Discrimination', in I. Chopin and J. Niessen (eds.), The Development of Legal Instruments to Combat Racism in a Diverse Europe (2004), 82-83.

55. The issue is analysed in detail in L. Farkas and D. Gergely, Racial Discrimination in Education and EU Equality Law (2020).

56. A. Xanthaki, 'Hope Dies Last: An EU Directive on Roma Integration', 11 (4) European Public Law, 515 (2005)

57. Communication from the Commission to the European Parliament, the Council, the European Economic and Social Committee and the Committee of the Regions, An EU Framework for National Roma Integration Strategies up to 2020, COM/2011/0173 final.

58. Guidance for member states on the use of European Structural and Investment Funds in tackling educational and spatial segregation, EGESIF_15-0024-01 11/11/2015, European Structural and Investment Funds (2015). cial proceedings in relation to discrimination against the Roma. ${ }^{59}$ Political consensus is missing on vigorous enforcement, which explains the Commission's caution and the focus on soft law measures. National courts have so far refused to make preliminary referrals on education; consequently, there is no CJEU case law to be discussed.

\subsection{International Case Law on Discrimination in Education Against the Roma}

Case law concerning the education of the Roma concerns segregation, rather than the structural and minority rights-related issues flagged in treaty body recommendations. International jurisprudence as concerns the Roma and discrimination in education emanates from the Strasbourg Court, due partly to the early and easy accessibility of the Convention, ${ }^{60}$ the geographic scope and the Court's leverage in Europe, but also the lack of preliminary references before the CJEU. ${ }^{61}$

The ECtHR has delivered six judgements in the socalled Roma education cases and found three other applications inadmissible. ${ }^{62}$ In the misdiagnosis cases, D.H. and Others v. the Czech Republic and Horváth and Kiss v. Hungary, the Court dealt with the overrepresentation and concomitant segregation of Roma children in special schools established to educate pupils with (mental) disabilities. Class-level segregation within the same school building and under the pretext of providing education with a view to bridging the language gap of the Roma, who are not native Croatian speakers, was addressed in Oršus and Others v. Croatia. In an analogous case, different buildings were reserved for ethnic majority and Roma students in Sampanis et autres c. Gréce. Two other cases examined segregation between Roma only and integrated schools. This resulted from white flight by ethnic majorities in Sampani et autres c. Gréce and the designation of catchment areas that failed

59. It launched pilot infringement proceedings against the Czech Republic Slovakia and Hungary on account of their non-compliance with the RED. It has moved to the next level as regards Slovakia, but the political will to see these cases through is weak. Infringement number 20142174 Czech Republic. Infringement number 20152025 Slovakia. Infringement number 20152206 Hungary.

60. While the states ratifying the European Convention are under the obligation to grant individuals the right to petition, this is not the case with UN treaties. The European Social Charter provides registered NGOs the right to lodge collective complaints without exhausting effective domestic remedies, but few Roma-dense member states have signed and ratified the relevant treaty provisions.

61. ECtHR case law provides the benchmark of adjudication under the Charter of Fundamental Rights of the European Union, Art. 52(3).

62. ECtHR, D.H. and Others v. the Czech Republic, [GC] application No. 57325/00, judgement of 13 November 2007, Sampanis and Others $v$. Greece, application No. 32526/05, judgement of 5 June 2008, Oršuš and Others v. Croatia, [GC] application No.15766/03, judgement of 16 March 2010, Ioanna Sampani et autres c Grece, requête No. 59608/09, arrêt 11 decembre 2012, Horváth and Kiss v. Hungary, judgement of 29 January 2013, and Lavida et autres c Grece, requête No. 7973/10, arrêt 30 mai 2013. Horváth and Vadászi v. Hungary, CFCF v. Hungary, and Amanda Kósa v. Hungary have been found inadmissible. Two additional applications communicated to Albania also concern school segregation by way of denying access to integrated schools. $X$ and Others v. Albania, application No. 73548/17 was communicated on 3 April 2019, while $X$ and $Y$ v. Albania, application No. 45521/19 was communicated on 18 December 2019. 
to address the consequences of residential segregation in Lavida et autres c. Gréce. ${ }^{63}$

The Court addressed (violent) resistance by non-Romani parents to integrated education, except in the misdiagnosis cases, and examined measures necessary to bring about integration in Oršuš, Horváth and Kiss, Sampani and Lavida. Except for D.H. and Oršus, the judgements became final without appeal, establishing discrimination in education. Importantly, the Court's qualification of unequal treatment as indirect discrimination explicitly only spelt out in D.H., Orsus and Horváth and Kiss - has been the subject of criticism. ${ }^{64}$

The Grand Chamber judgement in D.H. (2007) found that the overrepresentation of Roma children in special schools amounted to indirect discrimination and ordered the respondent state to pay EUR 4,000 to each applicant. It stated that parental consent should not be construed as overriding the children's right to equal treatment. ${ }^{65}$ The Court has done its utmost to render its reading consistent with relevant international treaties. Nonetheless, D.H. has not transformed the Court's application of the principle of equal treatment under Article 14 (treating persons in analogous situations unequally and those in different situations equally); thus, the Strasbourg equality maxim remains unchanged. The qualification of segregation as direct or indirect discrimination came to the centre of debate in the wake of the judgement. Some commentators argued that in certain instances segregation may amount to indirect discrimination; ${ }^{66}$ others noted that it should always be qualified as direct discrimination, bearing in mind in particular the persistent nature of these practices and

63. For more details, see Farkas (2014), above n. 47

64. M. Goodwin, 'Taking on Racial Segregation: The European Court of Human Rights at a Brown v. Board of Education Moment?', 3 Rechtsgeleerd Magazijn THEMIS 93 (2009); J. Devroye, 'The Case of D.H. and Others v. the Czech Republic', 7(1) North Western Journal of International Human Rights 81 (2009); R. Medda-Windischer, 'Dismantling Segregating Education and the European Court of Human Rights. D.H. and Others vs. Czech Republic: Towards an Inclusive Education?', 7/8 European Yearbook of Minority Issues (2007). H. O'Nions, 'Divide and Teach: Educational Inequality and the Roma', 14(3) International Journal of Human Rights 464 (2010). R. Drown, 'Equal Access to Quality Education' for Roma: How Indirect and Unintentional Discrimination Obstructs Progress', 31(2) Race Equality Teaching 32 (2013).

65. D.H. (GC) judgement para. 203: "In the circumstances of the present case, the Court is not satisfied that the parents of the Roma children, who were members of a disadvantaged community and often poorly educated, were capable of weighing up all the aspects of the situation and the consequences of giving their consent. ... It also appears indisputable that the Roma parents were faced with a dilemma: a choice between ordinary schools that were ill-equipped to cater for their children's social and cultural differences and in which their children risked isolation and ostracism, and special schools where the majority of the pupils were Roma. 204. In view of the fundamental importance of the prohibition of racial discrimination ... no waiver of the right not to be subjected to racial discrimination can be accepted, as it would be counter to an important public interest."

66. See, in particular S. Van den Bogaert, 'Roma Segregation in Education: Direct or Indirect Discrimination? An Analysis of the Parallels and Differences between Council Directive 2000/43/EC and Recent ECtHR Case Law on Roma Educational Matters', 71 Heidelberg Journal of International Law 719 (2011) and K. Arabadijeva, 'Challenging the School Segregation of Roma Children in Central and Eastern Europe', 20(1) The International Journal of Human Rights 33 (2016). the measures that serve to conceal their existence. ${ }^{67} \mathrm{It}$ could not be foretold at the time that the Strasbourg Court would not find discrimination justifiable in the Roma education cases, rendering concerns obsolete. ${ }^{68}$

$D . H$. has been perceived by critics as unnecessarily limiting the free choice of minority parents. ${ }^{69}$ Still, the limitation of majority parental choices prevalent in the Court's case law - particularly in the Greek cases seems to refute the suspicion of unjustifiable insensitivity vis-à-vis the Roma only. By finding segregation in violation of the Convention and imposing general measures on Greece and requiring its compliance as a matter of positive obligations, the Court curtailed the right of majority parents to choose segregated education for their children. ${ }^{70}$ The criticism put forward on behalf of the minority parents resonates with concerns about CADE's integrationist rationale, which imposes stringent conditions on ethnic self-segregation. Importantly, however, the judgement does not address minority education; rather, segregation based on the most invidious stigma, namely, the lower intellectual abilities of racial or ethnic minorities.

$D . H$. imposes obligations on minority as well as majority parents from the perspective of democratic pluralism, which requires the majority's tolerance vis-à-vis minorities. It can be read as a recognition of the many facets of vulnerability and an attempt to address the situation of the socio-economically disadvantaged Roma. The ECtHR grappled in this case with the power imbalance between impoverished Roma parents and majority institutions, recognising that perfect choices are not available to the former, because poverty-stricken Roma children are either segregated or regularly harassed in mainstream schools.

In Oršus, the Grand Chamber ruled in favour of the applicants (2010), establishing indirect discrimination and granting EURO 4,000 to each applicant. The case deals with the limits to and inadequacy of measures addressing the education of non-native speakers, requiring some sort of accommodation of their needs to enable their integrated education.

Four more verdicts were delivered in quick succession. What later became Horváth and Kiss v. Hungary was originally filed in 2005. The applicants won compensation for procedural failures in domestic courts, but the

67. See, in particular, Farkas (2014), above n. 47

68. For a detailed analysis, see, O.M. Arnardóttir, Equality and Non-Discrimination Under the European Convention on Human Rights (2003).

69. See, for instance, W.S. New, 'Litigating Exclusion, Inclusion and Separation: Dilemmas of Justice in Roma Education Reform', in M. Miskovic (ed.), Roma Education in Europe: Practices, Policies and Politics (2013) 189. See, also, 'Judicial Policy Making: The Role of the Courts in Promoting School Desegregation', in I. Rostas (ed.), Ten Years After A History of Roma School Desegregation in Central and Eastern Europe (2012) 91-127.

70. In the Greek cases the majority parents protested against integration. Outside the Roma rights context, parental choices have also been curtailed by the Court in relation to home schooling and non-attendance on the grounds of religious education. See, for instance, Konrad and Others v. Germany, application No. 35504/03, judgement of 11 September 2006 and Wunderlich v. Germany, application No. 18925/15, judgement of 10 January 2019 
Supreme Court refused to find structural discrimination, suggesting that systemic reform be sought from the Constitutional or the Strasbourg Court. By then, however, misdiagnosis was severely curtailed in Hungary by legal amendments adopted in 2007.

Kiss and Horváth is perhaps the most important ruling on account of the ECtHR's clear application of its positive obligations doctrine in the context of racial discrimination in education. In view of the persistent discriminatory practice at hand, the Court emphasised that

the systemic misdiagnosis of Roma children as mentally disabled has been a tool to segregate Roma children from non-Roma children in the Hungarian public school system since at least the 1970 s. $^{71}$

It further noted that the concept of 'familial disability' played the same role in the Hungarian context as the quasi-automatic placement of Romani children into Czech remedial schools '[owing] to real or perceived language and cultural differences between Roma and the majority', 72 while it found 'troubling that the national authorities significantly departed from the WHO standards'. ${ }^{73}$ Based on these antecedents, the Court concluded that 'the State has specific positive obligations to avoid the perpetuation of past discrimination or discriminative practices disguised in allegedly neutral tests' (emphasis added). ${ }^{74}$

In the Sampanis and Sampani judgements, the ECtHR held that public authorities are liable for segregation by omission, that is, by not taking measures to stem de facto/spontaneous segregation. In Sampani, the ECtHR did not find it an adequate justification defence that non-Roma parents chose not to register their children in the school with an obligation to enrol and that Greece had no power to stop this trend. ${ }^{75}$ In Sampani, the ECtHR prescribed general measures in order to avoid segregation.

\subsection{Assessment}

The Council of Europe's human rights regime protects minority rights under the Framework Convention, whose enforcement is limited to reporting. The accommodation of Roma-specific needs in the context of education has been dealt with by the Advisory Committee in the reporting process and specific publications.

Under the Convention and the Revised Charter, minority-specific needs can be raised either under the right to education or in claims that pertain to discrimination based on membership of a national minority in conjunction with education. Due to the lack of applications for the safeguarding of minority rights, the positive obligations doctrine has not developed in this direction, being thus limited to the issue of segregation and unequal education.

\footnotetext{
. Horváth and Kiss judgement, para. 9.

Ibid., para. 115

Ibid., para. 118

Ibid., para. 116

Sampani et autres judgement, paras. 103-104
}

Over time, the Strasbourg Court's approach grew bolder, motivated partly by the desire to decrease its own workload and increase its legitimacy. ${ }^{76}$ While the Court has powers to establish a violation and provide just satisfaction, ${ }^{77}$ it also uses the binding nature of judgements to impose individual and/or general measures. ${ }^{78}$ It has broadened the clout of its rulings in two ways in the Roma education cases: first, by prescribing general measures, and second, by imposing positive obligations. In Horváth and Kiss the Chamber finally bridged the normative prescriptions inherent in positive action concerning discrimination and positive obligations concerning general treaty obligations. Positive obligations address states rather than the general or minority population and the fulfilment of these obligations seems to be left to the discretion of states parties, with little or no oversight by the Committee of Ministers of compliance in the form of awareness-raising and trust-building efforts.

The positive obligations doctrine in the context of education was first fleshed out in D.H., and this judgement served as a benchmark for consecutive rulings as well. The Strasbourg Court's finding to the effect that Roma parents cannot lawfully consent to the segregation of their children if that would run counter to the prohibition of ethnic discrimination places a direct obligation on minority communities as concerns choice and conduct. Simultaneously, it also regulates the conduct of majority parents and institutions, in as much as D.H. renders it unlawful to exclude Roma children from integrated education.

The positive obligations in D.H. concern a particular practice of segregation, namely, the misdiagnosis of Roma children as mentally disabled; therefore, during the implementation phase, the Committee of Ministers has been focusing on the reform of diagnostic tools and the education system's response to misdiagnosis. In Orsus, the complaint dealt with segregation and only tangentially with the applicants' alleged linguistic deficiencies, so that even though the Court indicated a need to accommodate their needs in mainstream education, it did not engage with the obligation to provide education in the minority language. The equal treatment frame (integrated education) thus pre-empted considerations of special rights (minority language education).

In the Greek cases, the equal treatment frame was addressed by the Court by way of general measures to ensure that the applicants can access integrated education despite majority resistance. These measures can be considered as positive action aimed at equalising historic disadvantages but do not amount to special rights

76. The implementation of judgements by states parties reinforces its authority and alleviates the caseload, whose incessant increase weakened the Court's bargaining power on its budget.

77. Just satisfaction is available pursuant to Art. 41 of the Convention. The Court has carved out further remedial powers under Art. 46 that prescribes the binding nature of judgements on states.

78. V. Colandrea, 'On the Power of the European Court of Human Rights to Order Specific Non-monetary Measures: Some Remarks in Light of the Assanidze, Broniowski and Sejdovic Cases', 7(2) Human Rights Law Review 396 (2007) 
accommodating specific minority needs. In Horváth and Kiss the Strasbourg Court combined the two analogous approaches to strengthen the clout of its ruling. Given that this judgement does not concern the need to accommodate the applicants' minority-specific needs, the ECtHR's case law stops at rendering the positive obligations doctrine coherent with positive action in the context of equal treatment rather than the special rights. International litigation can seldom achieve what states are not prepared to grant. Indeed, the Czech Republic's endless legal and policy reforms triggered (partly) by $D . H$. bear witness to an avoidance technique, whereby nothing much is happening in practice, while an awful lot is going on 'on paper'. Legislative toing and froing has certainly not improved the Czech public's attitudes towards the Roma, nor necessarily towards children with disability, who are caught up in the D.H. saga on account of the focus on special schools. While the positive obligations doctrine may have resonated in the hearts and minds of Roma communities - particularly those targeted by litigation - it has not generated meaningful change in majority attitudes, to which the growing level of segregation attests.

In the context of the Roma education cases, the focus of academic research has been on the qualification of segregation and its remedies, rather than on positive obligations. Little has been said about the fact that notwithstanding its undisputable strengths, the Strasbourg approach runs counter to international human rights norms that categorically prohibit segregation, undermines the conception of segregation as an ipso iure form of discrimination (prohibiting segregation by the law itself) and remains oblivious to concealment techniques that hide from view the intent to separate Roma students and the failure to end spontaneous segregation. The application of the proportionality test in the Roma education cases creates inconsistencies with UN treaties and opens the door to reading down domestic antidiscrimination law. Moreover, the Strasbourg approach seems to require that applicants show the existence of intent on the part of state authorities to make a finding of direct discrimination. As it is, even a state's unacceptable (in)action will lead to a finding of indirect discrimination, unless discriminatory intent is proven. ${ }^{79}$

Before turning to housing litigation, one aspect needs to be clarified, namely, why has the Strasbourg Court relied so heavily on the principle of equal treatment in the field of education, and why has it failed to do so in other fields? The answer is relatively straightforward. As long as the violation of a substantive right can be established, the Court tends to focus its reasoning on that aspect, weaving arguments about equal treatment

79. For instance, in Lavida, the Court held that 'in the absence of any discriminatory intent on the part of the State, the Court considers that the continuation of the education of Roma children in a public school attended exclusively by Roma and the decision against effective desegregation measures - for example, dividing the Roma in mixed classes in other schools or redrawing catchment areas - due in particular to the opposition of parents of non-Roma pupils, cannot be regarded as objectively justified by a legitimate aim' Lavida et autres judgement, para. 73. into the primary thread of reasoning in line with the nature of Article 14. To trigger protection under the principle of equal treatment safeguarded in Article 14, the Court must deal with a substantive right violation, which therefore takes the limelight away from the discrimination analysis. In the Roma education cases, this logic could not apply, because of the nature of education as a right as well as an obligation. Given that all complainants had access to education, violation of the substantive right alone was not at issue. The only issue before the Court was discrimination in education.

\section{Roma Rights in the Field of Housing}

Roma rights litigation in the field of housing began three decades ago, being thus greater in volume, even if less known than the Roma education cases. The number of complaints before international tribunals and the intensity of community involvement indicate that the right to housing is of paramount importance for the Roma and the Travellers themselves. Housing litigation has mobilised a wide array of (inter)national tribunals, primarily the Strasbourg Court. Even though the EU RED has facilitated housing litigation at the national level, it has not triggered meaningful case law from the CJEU. ${ }^{80}$

Several considerations can explain why education case law has taken precedence over housing jurisprudence. First, the right to housing in social rights treaties - Article 11 ICESCR and Article 31 of the European Social Charter (Revised) ${ }^{81}$ - became accessible relatively late and only in a limited number of EU member states. Earlier, international litigation focused on the Strasbourg Court, where it took time for housing jurisprudence to mature given that the Convention does not safeguard the right to housing per se. The proper frame and argument had to be identified by lawyers and judges. Second, resources for education litigation have been vastly greater and the cause has been supported by international organisations seeking to use school desegregation as a vehicle of their social inclusion agenda.

\subsection{International Law Governing the Right to (Racially Equal) Housing}

International standards on the right to housing show similarities, but also differences, as compared with education. First of all, a treaty concerning minority identity and housing - like CADE in education - is lacking, and

80. See, further, T. Kádár, 'The Standing of National Equality Bodies before the European Union Court of Justice: The Implications of the Belov Judgment', 11 Equal Rights Review 13 (2013) and S.B. Lahuerta, 'Ethnic Discrimination, Discrimination by Association and the Roma Community: CHEZ', 53(3) CMLR 797 (2016).

81. Art. 11.1 ICESCR stipulates that states parties recognise the right of everyone to an adequate standard of living for himself and his family, including housing. The European Social Charter (Revised) provides for the right to housing under Art. 31 
second, the explicit protection of the right to housing and the prohibition of discrimination in treaties governing social rights are augmented by provisions that can trigger protection under treaties governing civil and political rights for certain aspects of housing, such as forced evictions. Protection from forced evictions can be sought under the right to private and family life; therefore, the analysis in Section 3.1 is pertinent when it comes to Article 8 of the European Convention and Article 17 of the ICCPR. ${ }^{82}$

The analysis concerning protection from segregation under the ECHR and the EU RED applies to housing as well, with the caveat that Article 3 of the Directive covers discriminatory scenarios concerning the allocation of social housing under the heading 'social protection', while racial or ethnic discrimination in relation to private housing is covered under the heading 'services available to the public'.

The 2000 CERD General Recommendation contains a three-tiered approach to housing. The first tier focuses on 'avoiding segregation' by appropriate planning and partnering with the Roma and charitable organisations in the construction, rehabilitation and maintenance of housing. The second tier addresses the need to 'firmly' tackle discrimination by local authorities and private owners both in relation to 'taking up residence and access to housing', particularly when it comes to unlawful expulsion and the placement of 'Roma in camps' in remote areas without access to public utilities. The third tier requires that measures be taken for the culturally adequate accommodation of Roma nomadic groups and Travellers.

Given the scarcity of social housing in the CEE, the Roma's access to accommodation in social housing features high on the list of CERD recommendations, while with the rise of forced evictions, the Committee is calling on states to put an end to this practice and provide alternative accommodation across Europe. This should, at times, necessitate legal reform, as borne out, for instance, in the concluding observations of the Human Rights Committee (HRC) on Bulgaria. ${ }^{83}$

In relation to Italy, the CERD recommends that the state party halt plans to carry out further evictions, end the use of segregated camps, ensure the provision of adequate and culturally appropriate accommodation as a matter of priority and review and amend housing legislation, policies and practices at all levels to end discrimination in access to social housing and housing benefits. ${ }^{84}$ In addition, the HRC recommends that the Italian government ensure that specific security measures imposed on segregated Roma-only settlements are repealed. ${ }^{85}$ With respect to France, the CERD recommended that

82. Art. 17 ICCPR stipulates that no person shall be subjected to arbitrary or unlawful interference with his privacy, family and home.

83. Human Rights Committee, Concluding observations on the fourth periodic report of Bulgaria, 4 (2018).

84. CERD, Concluding observations on the combined nineteenth and twentieth periodic reports of Italy, 7 (2017).

85. Human Rights Committee, Concluding observations on the sixth periodic report of Italy, 3 (2017). the Besson Act, regulating the right to housing, 'be implemented swiftly' and that travel permits for Travellers be abolished. ${ }^{86}$

\subsection{International Case Law on the Right to Housing}

Given the prolific nature of housing litigation, this section discusses case law in the framework of relevant strategies through which applicants channel their arguments. It must be noted at the outset that regardless of the strategy that yields applications, reference to the principle of equal treatment enshrined in Article 14 of the European Convention is almost non-existent in the Strasbourg Court's case law. As mentioned above, this is because the Court tends to resolve matters concerning equal treatment in its analysis of a violation of core Convention rights, such as the right to private and family life under Article 8 in the housing context, without then taking up claims that combine unequal treatment with the violation of core rights.

\subsubsection{Civil Rights Strategy}

The European Convention was first engaged by the Traveller litigation campaign launched in the United Kingdom in the early 1990s. Seeking the annulment of legislation repressing the Travelling way of life, the campaign yielded complaints under the right to private and family life (Art. 8) in conjunction with the principle of equal treatment (Art. 14). ${ }^{87}$ The campaign coincided with the accession of Roma-dense CEE countries, which made Traveller litigation relevant for the Roma. ${ }^{88}$

The United Kingdom gradually curtailed the right of Travellers and Gypsies to lawfully stop and park their caravans. As a knock-on effect, they lost security of tenure and access to social services, education and so on. Adopted in 1994, the Criminal Justice and Public Order Act repealed the duty of local authorities to accommodate Travellers and Gypsies. It also abolished the statutory, full-scale budgetary grants for site provision, while giving wider powers to local authorities and the police to evict, effectively criminalising those unable or unwilling to find lawful halting sites. ${ }^{89}$ Planning regulation made it more cumbersome to obtain permission to buy land and park caravans there. ${ }^{90}$

Travellers wanted to preserve the status quo, but the government's intention to restrict 'new nomads', whose numbers increased after the 1980s and who were not members of the ethnic group, exacerbated their struggle. ${ }^{91}$ Despite a generous legal aid scheme, only 'proce-

86. CERD, Concluding observations on France, 4 (2010).

87. Prior to the 1994 legislation, complaints were found inadmissible. See, L. Clements, P.A. Thomas \& R. Thomas, 'The Rights of Minorities-A Romany Perspective', 4(4) ODIHR Bulletin 3 (1996).

88. In the United Kingdom, Gypsies were protected under the Race Relations Act.

89. R. Morris and L. Clements, At What Cost? The Economics of Gypsy and Traveller Encampments (2002)

90. D. Hawes, The Gypsy and the State (1995).

91. L. Clements, 'Human Rights and Gypsy Identity in British Law', in A. Simoni (ed.), Stato Di Diritto E Identita Ro-M (2003). 
dural access to justice' could be obtained, without substantive changes on the ground. ${ }^{92}$

Given the lack of regional norms on minority rights at the time, the Traveller cases were framed as discrimination under the European Convention in conjunction with the right to private and family life, given that discrimination can only be established if there is an arguable claim under a Convention right. The ambivalence to minority rights, ${ }^{93}$ compounded by the difficulty to fit Travellers under the minority category and the misuse of this frame by ethnic majority caravan dwellers, hampered admissibility. ${ }^{94}$

Prior to Buckley v. the United Kingdom, complaints were found inadmissible. ${ }^{95}$ The first applications to reach the Court were those of Fones v. the United Kingdom ${ }^{96}$ and Smith and Others v. the United Kingdom. ${ }^{97}$ The former bears little jurisprudential value, but in the latter, the Commission held that, in principle, the traditional lifestyle of a minority attracts the protection afforded by Article 8. However, given that the applicants' complaints touched upon questions of policy and public administration, issues that the Commission was rather ill-suited to address, the complaints were ill-founded.

The great breakthrough in Buckley, which concerned the criminalisation of the occupancy of land by English Gypsies, was admissibility itself. Earlier, the Commission's test appeared 'disproportionately harsh'. ${ }^{98}$ Even though the Council of Europe was the first international organisation to single out Roma and Travellers for protection, a quarter century passed between the adoption of its recommendation on 'Gypsies and other travellers' in 1969 and the admissibility decision in Buckley. ${ }^{99}$

The Strasbourg Court did not find a violation in Buckley, missing the momentum to critique discriminatory legislation that could have reverberated across Europe. ${ }^{100}$ It did, however, seize the momentum to note obiter dicta that

the vulnerable position of Gypsies as a minority means that some special consideration should be given to their needs and their different lifestyle both in the relevant regulatory planning framework and in reaching decisions in particular cases. ${ }^{101}$

92. P. Wheeler, 'Accessing Legal Services - Traditional Travellers in England and Wales', 1 J. C.L. 230 (1996) 244

93. Clements et al., above n. 87. The '... creation of a Sub-Committee on Minorities in 1957 and a proposal in 1959 for an additional Protocol on Minorities. Since that time the Protocol has remained on the drawing board for 37 years, with the Parliamentary Assembly becoming ever more insistent about the need for its adoption'.

94. Ibid.

95. Buckley v. the United Kingdom, judgement of 25 September 1996.

96. Jones $v$. the United Kingdom, application no. 14837/89, 7 May 1990. An even earlier case was struck off the list. See Drake v. the U.K., application no. 11748/85, 7 May 1990.

97. Smith and Others v. the United Kingdom, Application no. 14455/88, 4 September 1991.

98. Clements et al., above n. 87

99. Recommendation 563 (1969) of the Consultative Assembly on the situation of Gypsies and other travellers in Europe (1969).

100. N. Gughinski, 'The European Court of Human Rights Turns Down the First Case Involving a Gypsy Applicant', 1 Roma Rights 25 (1996).

101. Buckley judgement, paras. 76,80 and 84 .
This embryonic formulation of a positive obligation was considered inadequate by Judge Lohmus, who wished to go further, observing that equal treatment in case of an ethnic minority required special measures. Judge Pettiti urged the Court to adopt a more activist approach also with a view to the Eastern Roma, while Judge Repik was concerned about the message the Court's first Roma rights judgement would send.

Despite defeat, the Traveller cases nevertheless constitute evolutionary milestones in the jurisprudence, because they enabled the Court to crystallise its approach to minority-specific housing. ${ }^{102}$ The Court considered that states are under an obligation to facilitate the 'Gypsy way of life', ${ }^{103}$ while intimating that it will be willing to review its jurisprudence inasmuch as a pan-European consensus emerges. ${ }^{104}$ A very important (and often overlooked) aspect relates to the Court's holding that, in cases of eviction, the availability and provision by the authorities of alternative accommodation are countervailing factors that should be taken into account when assessing the proportionality of the interference, thereby suggesting that an eviction not accompanied by provision of alternative accommodation might run counter to Article $8 .{ }^{105}$ In sum, the Traveller litigation campaign lay the ground for the Court's robust approach in later cases on positive obligations, including culturally appropriate alternative accommodation.

In Connors v. the United Kingdom, ${ }^{106}$ the first successful Traveller complaint, the Court held that the eviction was not attended by any due process safeguards and was therefore in breach of Article 8's procedural limb. The applicant's living in a lawfully established site distinguished Connors from the previous cases, but also limited its jurisprudential value. Regrettably, the Court did not provide any directions to the respondent state as to the measures it should take in order to comply with the judgement. ${ }^{107}$

In Codona v. the United Kingdom, the applicant challenged the nature of the alternative accommodation provided in the wake of eviction, ${ }^{108}$ affirming that she was averse to 'bricks and mortar' accommodation and preferred instead the allocation of a new site for her caravan. The Court found this application inadmissible, while interestingly reviewing the Article 14 arguments, only to reject them by noting that in such emergency cases, both the applicant and her comparator would

102. Chapman v. United Kingdom, application no. 27238/95; Beard v. United Kingdom, application no. 24882/94; Coster v. United Kingdom, application no. 24876/94; Lee v. United Kingdom, application no. 25289/94; Jane Smith v. United Kingdom, application no. 25154/94. All five cases were joined by the Grand Chamber that delivered its judgement on 18 January 2001.

103. Chapman, para. 96

104. Ibid., para. 70.

105. Ibid., para. 103

106. Connors v. the United Kingdom, application no. 66746/01, judgement of 27 May 2004.

107. Regarding the Connors judgement, it would be only in April 2011 and only in relation to England that the relevant legislation would be amended.

108. Codona v. the United Kingdom, application no. 485/05, 7 February 2006. 
have been provided with the same kind of accommodation. The ruling did not clarify whether a specific minority need could in fact have an ethnic majority comparator. In Buckland v. the United Kingdom, ${ }^{109}$ the Court applied for the first time the proportionality test to the eviction order, which became the cornerstone of its Article 8 jurisprudence in the landmark case of Yordanova and Others v. Bulgaria discussed later in this article. $^{110}$

Over time, the Court's majority became more sympathetic to the cause, ${ }^{111}$ and a growing number of judges steered adjudication towards a more robust reading of minority rights. ${ }^{112}$ Nonetheless, the Court did not go as far as to impose a duty on states parties to adopt positive action measures to remedy past discrimination. ${ }^{113}$ This would have been impossible, given that discrimination in the Traveller cases was not in fact established.

The synchronicity of regional standard setting on minority rights, awareness of the situation of Eastern Roma and the adjudication of Traveller complaints created a fortunate constellation. Before examining a single Roma complaint from the East, the Strasbourg Court recognised the group's vulnerability and lay the foundations of its positive obligations jurisprudence concerning housing. The Court's activism was needed to make the link between the Traveller and Roma causes and merge the two minority groups into one legal category with a view to reinforcing an emerging political consensus. Without the accession of Roma-dense CEE states and standard setting on minority rights, the judicial recognition would have taken longer or would not have occurred. Had it not been for the Traveller cases, the Roma may have had to wait longer for recognition. As it is, Travellers won the battle for the whole group.

In the East, it took considerable time to find the most effective argument and forum in cases of forced eviction due to the mismatches between domestic and international legal opportunities. Nonetheless, by 2009, when the FRA report on the minority's housing rights made apparent the lack of Roma-related case law, ${ }^{114}$ the issue of forced evictions of Roma communities in the CEE had already been channelled to the Strasbourg Court in Yordanova and Others v. Bulgaria.

The case concerns the eviction of a Roma community that had settled in a locality of Sofia in the early 1960 s

109. Ibid., para. 68.

110. Yordanova and Others v. Bulgaria, application no. 25446/06, judgement of 24 April 2012.

111. In Chapman, the majority recognised that vulnerability resulted from an asymmetry between the situation of the Roma and Travellers as compared to ethnic majorities, which merited different treatment both in administrative practice and legislation. Chapman, para. 96.

112. L. Clements, 'An Emerging Consensus on the Special Needs of Minorities: The Lessons of Chapman v. United Kingdom, Roma Rights', 2 Roma Rights 8 (2001) and R. Sandland, 'Developing a Jurisprudence of Difference: The Protection of the Human Rights of Travelling Peoples by the European Court of Human Rights', 8(3) Human Rights Law Review 475 (2008).

113. C. Cahn, 'Towards Realising a Right to Positive Action for Roma in Europe: Connors v. UK', 1 Roma Rights 13 (2005)

114. FRA, Housing Conditions of Roma and Travellers in the European Union (2009). and built their houses without planning permissions. The local municipality decided to evict them, and following an unsuccessful judicial challenge, the applicants lodged a complaint with the Court. The Court - for the first time in the housing context - indicated interim measures to the Bulgarian government in July 2008, requesting the suspension of the execution of the final domestic court decision that authorised the applicants' eviction.

The Court's final judgement was even more groundbreaking: while reiterating that Article 8 did not provide for a right to a home, it was nevertheless held that such an obligation could arise, under exceptional circumstances, with a view to securing shelter to 'particularly vulnerable individuals'. The fact that the applicants themselves had not benefitted from the government's policy initiatives weighed heavily in the Court's finding of a violation under Article 8, despite some share of responsibility attributable to the Roma. The Court called upon the Bulgarian authorities to amend the relevant legal framework and allow for the review of the proportionality of the eviction order, to either repeal the final domestic decision concerning eviction or suspend it pending the applicants' housing rehabilitation.

A year later, the Court halted the eviction of 26 gens $d u$ voyage families in Winterstein et autres c. France. ${ }^{115}$ The true significance of the French case lies in the wide interpretation of positive obligations concerning protection from forced evictions mindful of the cultural adequacy of alternative accommodation. Pursuant to Winterstein, states must provide culturally adequate alternative accommodation, except in cases of force majeure.

The Winterstein applicants lived on private land, as tenants, owners or squatters; still, the Court found the principles enunciated in Yordanova fully applicable to the case. Moreover, it found a separate Article 8 violation on account of the failure of the authorities to provide culturally adequate alternative accommodation to those semi-sedentary applicants who refused majoritarian social housing. This does not, however, imply a full recognition of a right to culturally sensitive accommodation; rather, the Court felt emboldened by the fact that such a right was recognised under French law.

The civil rights strategy was pursued in cases before the HRC, with the caveat that reference to minority rights is available before that tribunal. The first Roma housing case to reach the UNHRC was Georgopoulos and Others v. Greece. ${ }^{116}$ The HRC found that the applicant and his family's consecutive evictions were in violation of the ICCPR - including the right to protection of minorities - and called upon Greece to provide an effective remedy as well as adequate reparation, including compensation. It also reminded Greece of its obligation to ensure that no similar violations take place in the future.

115. Winterstein et autres c France, application no. 27013/07, judgement of 17 October 2013

116. HRC, Georgopoulos and Others v. Greece, communication no. 1799/2008, views adopted on 29 July 2010 
The case of Naidenova and Others v. Bulgaria ${ }^{117}$ is the HRC's equivalent of Yordanova. The HRC held that the eviction would be in violation of the ICCPR, unless satisfactory replacement housing was made available immediately. ${ }^{118}$ The case of Cultural Association of Greek Gypsies Originating in Halkida and Suburbs 'I Elpida' and $M r$. Stylianos Kalamiotis v. Greece ${ }^{119}$ was analogous to Naidenova. The HRC held that eviction without provision of 'alternative accommodation immediately' would be in violation of the Covenant. The municipality has made use of a series of government-funded programmes (including rent subsidies) to implement the verdict.

\subsubsection{Social Rights Strategy}

The ECSR is accessible from few Roma-dense countries, which severely hampers its clout on Roma rights. Legal action was first channelled to the ECSR in 2004, when the European Social Charter (Revised) came into force. The social rights strategy was short lived in the Roma context, which is partly due to the unavailability of collective complaints ${ }^{120}$ in the majority of Romadense CEE countries and the weak pulling effect of the Charter itself. ${ }^{121}$

Pursuant to the Committee's progressive jurisprudence, states must show due regard for the specific circumstances of the Travellers and the Roma in both legislation and decision-making, while serving the public interest by striking the right balance between the interests of the minority and the majority. ${ }^{122}$ Furthermore, states have the duty to adopt an overall and coordinated approach, consisting of an analytical framework, a set of priorities and measures and a monitoring mechanism involving all stakeholders. ${ }^{123}$ The Committee set out requirements for national legislation by turning the limelight away from the question of whether illegal occupation may justify evictions to whether the criteria of illegal occupation are unduly wide, including conditions such as permanent residence or domiciliation on which access to healthcare, education and other social services are conditioned. ${ }^{124}$ This approach is based on the realisation that evictions render the Roma effectively homeless, because individuals or groups are in fact forced to behave reprehensibly, if their membership in a minority would otherwise prevent their enjoyment of a

117. HRC, Naidenova and Others v. Bulgaria, communication no. 2073/2011, views adopted on 20 October 2012.

118. Human Rights Treaties Division Letter to Ms Mihailova and Mr Thiele 9 May 2012.

119. Cultural Association of Greek Gypsies Originating in Halkida and Suburbs 'I Elpida' and Mr. Stylianos Kalamiotis v. Greece, communication no. 2242/2013, views adopted on 3 November 2016.

120. Even where collective complaint is available, the majority of domestic NGOs are not registered with the Committee.

121. European Roma Rights Centre v. France, Complaint No. 51/2008, decision of 19 October 2009, paras. 93 and 51

122. Centre on Housing Rights and Evictions v. Italy, Complaint No. 58/2009, decision of 25 June 2010, paras. 39-40.

123. European Roma Rights Centre v. France, Complaint No. 51/2008, decision of 19 October 2009, para. 93.

124. European Roma Rights Centre v. Greece, Complaint No. 15/2003, decision of 8 December 2004, para. 51 and International Federation of Human Rights v. Belgium, Complaint No. 62/2010, decision of 21 March 2012, paras. 168-182. right in a manner enshrined in national legislation. Legislative amendment is needed to ensure the compatibility of minority identity and majority legal norms, so that evictions do not result in homelessness. ${ }^{125}$

The lack of domestic litigation inherent in the collective complaint mechanism means that the ECSR jurisprudence does not resonate at the national level. Another reason why the Committee's progressive jurisprudence has not become a standard reference is the mismatch between the social rights and the equality frames and the latter's dominant influence on legal strategies in the CEE.

\subsubsection{The Equal Treatment Strategy}

The equal treatment strategy has not contributed meaningfully to the doctrine of positive obligations, because under ICERD - where it could be fleshed out - only one complaint has been made so far, and also because under EU anti-discrimination law - which has been used in housing litigation - compliance is ensured in different ways.

L. $R$ and Others v. Slovakia ${ }^{126}$ originated in a resolution, adopted by the Municipal Council of the town of Dobšiná in Slovakia, approving a housing policy for the local Roma community. Local non-Roma residents petitioned the municipality not to proceed with the housing plan, and the Council abandoned the project. In its March 2005 opinion, the CERD Committee found the revocation of the first municipal resolution to be racially motivated and in violation of the state's obligation to ensure that all authorities exercise their functions in a non-discriminatory manner as well as the obligation to provide for effective remedies in cases of discrimination. The CERD held that the authorities should reinstate the status quo ex ante and proceed with the housing plan. Slovakia did not comply.

Housing litigation often relies on EU anti-discrimination law at the national level. Importantly, positive obligations or injunctive relief is either not available or not imposed, while damages granted ex post - the RED's key feature - cannot adequately remedy forced evictions. Cazacliu and Others v. Romania demonstrates that once some sort of remedy is provided, even the Strasbourg Court will be disinclined to review its (cultural) adequacy. ${ }^{127}$ Litigating in the equality frame may be counterproductive when it comes to housing and specific minority accommodation because claims for special treatment cannot be addressed under this frame, unlike under the aforementioned civil or social rights frames. Moreover, at the EU level, even the shocking French eviction and expulsion campaign failed to trigger action. Due to insufficient political support in the

125. European Roma Rights Centre v. Bulgaria, Complaint No. 31/2005, decision of 18 October 2006, paras. 53 and 57, and European Roma Rights Centre v. Italy, Complaint No. 27/2004, decision of 7 December 2005, para. 21

126. CERD, L.R and Others v. Slovakia, No. 31/2015, opinion of 7 March 2005.

127. ECtHR, Aurel Cazacliu and others against Romania, application no. 63945/09, decision on inadmissibility of 4 April 2017. 
Commission, France was finally condemned by the ECSR. ${ }^{128}$

\subsection{Analysis}

Housing litigation in the Strasbourg Court commenced with complaints from Western Travellers who sought the accommodation of their minority-specific needs under the ambit of the right to private and family life with reference to due process in the legislative as well as the policy context. This approach framed the Court's jurisprudence in subsequent Traveller as well as Roma cases, even though the Roma invoked community ties as an important value rather than culture-specific accommodation.

Positive obligations under Article 8 require states to consider the cultural specificities of the minority during the legislative, policy and administrative processes to the effect that they tolerate - in other words, refrain from outlawing - self-segregated, non-majoritarian ways of life. In case minority dwellings are situated on public land, compliance with the Court's and the Social Committee's case law requires a type of culture-specific (social) housing provision. In case dwellings are situated on private land owned by minority individuals, the obligation entails no interference. As far as private landowners from the majority are concerned, they can seek protection for their property rights, but states are under the obligation to provide alternative, culture-specific accommodation to members of the minority group.

As concerns compliance, approaches in the East and the West differ because in the latter context legislatures and judiciaries - and in their wake, hopefully societies slowly learn to tolerate self-segregation. In the East, national legislation and policies do not comply with the standards of the Strasbourg tribunals. In the CEE, authorities routinely use the law to exclude the Roma from integrated spaces, ${ }^{129}$ against which equality arguments are inadequate, being irrelevant for the small group of middle-class Roma, who can actually afford housing in integrated districts, but even more so for those who lack the means to rebel against the status quo. Legislation accommodating minority needs is needed to ensure their right to housing.

Compliance is not perfect in the West either, even though the situation is markedly improving. ${ }^{130}$ The United Kingdom slowly amended its legislation, and unfavourable case law has recently taken a positive

128. European Roma and Travellers Forum v. France, Complaint No. 64/2011, decision of 24 January 2012.

129. High Court of Cassation and Justice, Romania, file 1741/33/2011, decision no. 640/27.09.2013.

130. For instance, in September 1998, Ireland adopted the Housing (Traveller Accommodation) Act, placing all local authorities under the duty to adopt a five-year programme for the creation of halting sites. New halting sites law for Irish Travellers. Failure to adopt a halting site plan automatically ceded competence to civil servants, whose approach is generally more favourable. Still, in 2015, the ECSR found Ireland in violation of the Charter for failing to provide a sufficient number of sites. European Roma Rights Centre v. Ireland, Complaint No. 100/2013, decision of 1 December 2015. turn. ${ }^{131}$ In France, special legislation ${ }^{132}$ protects everyone from homelessness, and mayors have the duty to ensure that a sufficient number and quality of halting sites are available. ${ }^{133}$ The duty is regularly breached and mayors are rarely sanctioned, even though French high courts tend to rule in favour of occupants ${ }^{134}$ and the French equality body has made efforts to end status inequality hindering access to social rights. ${ }^{135}$ Bureaucratic contingency is problematic in Belgium too. ${ }^{136}$ France's ongoing expulsion policy shows most vividly that the hearts and minds of Westerners may not have changed much when it comes to migrant Roma from the CEE. Presently, half a dozen housing complaints are pending before the Strasbourg Court, and lawyers call for mass filings. ${ }^{137}$ Interim measures can defer but cannot resolve the eviction disaster. ${ }^{138}$

\section{Conclusions}

The ECtHR has been at the forefront of jurisprudential developments concerning positive obligations in Roma rights cases dealing with integrated education and forced evictions. The Court's Article 8 jurisprudence accommodates cultural differences in the latter context through due process reasoning. The protection of special minority rights upholds self-segregation, with reference to the positive aspects of ethnic identity and community ties. The Court recognises the need of Roma and Traveller minorities to 'stick together' in the face of racial harassment by ethnic majority neighbours and local authorities, which is a permanent feature of their life and complaints. Minority rights claims have not been raised under the right to education. Rather, the

131. Davis and Others v. Tonbridge and Malling Borough Council, Court of Appeal of England and Wales, CA 26 February 2004, [2004] EWCA Civ 194, See, however, Wrexham County Borough Council v. Berry; South Buckinghamshire District Council v. Porter and Another; Chichester District Council v. Searle and Others, House of Lords, 22 MAY 2003, [2003] UKHL 26, [2003] 2 WLR 1547, [2003] 2 AC 558.

132. Loi no 90-449 du 31 mai 1990 visant a mettre en oeuvre le droit au logement (Lois Besson).

133. J. Charlemagne, Le droit au logement des gens du voyage: un droit en trompe l'oeil?, 15 Etudes tsiganes, 66 (2000).

134. D. Schaffhauser, Droits des occupants de terrain : Evolution récente de la jurisprudence (Intervention au séminaire interrégional d'avocats du 18 mars 2016. See, most recently, Conseil d'État, $N^{\circ} 427423$, CLI:FR:CEORD:2019:427423.20190213, 13 février 2019.

135. The National Assembly adopted a bill on 9 June 2015 to repeal Law no 69-3 of 3 January 1969 on Travellers, ending their obligation to carry special identity papers. The bill gives effect to the French equality body's recommendations and condemnation by the UN Human Rights Committee and the Conseil d'Etat that invalidated this part of the law.

136. FIDH v. Belgium, ECSR, para. 146.

137. T. Alexandridis and A. Dobrushi, 'International Housing Rights and Domestic Prejudice: The Case of Roma and Travellers', in M. Langford, C. Rodríguez-Garavito \& J. Rossi (eds.), Social Rights Judgments and the Politics of Compliance: Making It Stick (2017).

138. D. Mihaylova and A. Kachamov, Roma Evictions and Demolition of Roma Houses: A Sustainable Solution for Roma Integration or a Problem of Roma Discrimination in Bulgaria? Analysis of the Legislation Regulating the Demolition of Illegal Housing and Its Implementation in Bulgaria to Identify Its Compliance with the EU Legislation on Protection from Discrimination on Grounds of Ethnic Origin (2017). 
positive obligations doctrine has emerged in response to complaints promoting integrated education.

Jurisprudential differences in the two fields stem from the function of education in the nation-building project. Education as an obligation is a means of assimilation with majoritarian history, language and values, which explains why the Roma are not en bloc excluded from schools, albeit increasingly excluded from integrated education. Some provision is made to accommodate their minority traits, but education systems are rather rigid in this respect. Conversely, due to historic oppression, Roma communities lack the internal resources needed for minority language education or self-segregation in minority schools, which explains why these types of claims do not come before international tribunals.

Challenges in housing arise in relation to the minority group's culturally adequate accommodation and its toleration in the proximity of non-Roma, especially when legislation, policy or administrative practice fails to take into account minority specificities. The right to housing - inasmuch as covered by Article 8 of the Convention is not connected to the assimilationist agenda as is education, meaning that the right is not augmented with a corresponding obligation to provide housing even if under discriminatory or segregated conditions. The lack of such inherent obligation at the national level renders claim making - legal as well as political - more frequent in the housing context. The nature of exclusion is dependent on the field, because segregation does not absolutely exclude Roma children from educational institutions, whereas housing legislation and practices often pursue this aim, failing only because of the impossibility of the task, lest the policy aim is expulsion - of non-citizens - or genocide. The nature of exclusion and minority responses explain both the variability of litigation trends and positive obligations jurisprudence in the two fields.

Positive obligations can naturally achieve a higher level of compliance in situations in which they ask less of stakeholders. Rulings in the field of housing require small steps from legislatures and policymakers and a bit of tolerance from majority populations, while improving the situation of the Roma and the Travellers tremendously. The situation is fundamentally different when it comes to education, where legal and institutional reform, but also a fundamental change in the hearts and minds of both majority and minority groups, would be necessary to bridge the social distance and generate mutual trust between ethnic majorities and the minority. Integrated education places severe demands on public education systems, particularly if they also cater for needs to stand apart.

Importantly, Roma communities have not used the law's adversarial powers to claim special rights in education, nor to eliminate segregation in housing. Structural constraints, including the lack of resources within the community and the lack of pre-existing minority institutions and linguistic standardisation, explain this in the context of education. In housing, community ties signify impor- tant resources for the Roma, who suffer from extreme levels of social exclusion and harassment.

The article has explored the differences in the manner and extent to which jurisprudence has impacted Westerners and Easterners vis-à-vis the Roma at home and abroad. Eastern Roma gained powerful allies in Western states and international organisations as long as they stayed at home, while the 'Europeanisation' of Roma rights leveraged the situation of Travellers and Roma in Western Europe belatedly. These developments have passed by Eastern societies. International tribunals have undoubtedly contributed to the development of a legally more conscious Roma minority, while causing dismay in various strata of majority societies as an inevitable reaction to legal mobilisation by a historically disenfranchised group. Sadly, attitudinal studies have not found meaningful change in Romaphobic prejudice.

Change is incremental and often circular. While the minds of decision makers may be swayed by international dicta, ingrained social prejudices are more resilient to change. The language in reports and policy documents inspired by monitoring bodies is more amenable to legal and policy reform at the national level but achieving more systemic attitudinal and societal change at the local level is an arduous task. It is a hard job not only for the law, but also for other social change tools.

Local power structures resist reform, particularly with respect to the participation and inclusion of minorities. Members of the Roma community are seldom admitted to the decision-making table to oversee the distribution of public funds, access to good schools and housing within city limits. A mismatch between the discourse and the action of local and national agents is greater than between the representatives of states parties and international organisations. Bureaucratic contingency, the resistance of the local administration bending to the pressure of majority constituencies hampers actual change, often deflating central reform initiatives, particularly in countries that lack the resources to implement or simply neglect the implementation of their own measures.

Legal proceedings are time bound, and the law's engagement with an issue or a community is seldom sustained over a longer period due to resource constraints. Local resistance may prevail even in situations in which long-term investment is made to foster social change, as the example of desegregation shows. Conversely, there is strength in individual complaints, as borne out by the Traveller litigation campaign.

The final conclusion is that it is worth studying longterm processes prospectively, with specific attention to the emergence and accessibility of legal opportunities, the ebbing and flowing of judicial activism, the rising and subsiding importance of European politics, community resources and assimilation trends. These factors explain why the right to family life has become the vantage point for the development of the positive obligations doctrine under the ECHR and the (Revised) Social Charter. EU law's compliance toolbox places emphasis on different measures, while in the UN context, moni- 
toring rather than litigation yields important insights on positive obligations. The weak justiciability of minority rights, the lack of resources internal to the community, but also a high level of political assimilation among the Roma, impede legal claims for special rights in education. Conversely, the protection of minority identity and community ties is of paramount importance in the housing context, which is where the most significant change has occurred in the hearts and minds of both the majority and the minority, albeit more so in the West than the East of Europe. 